\title{
КОММУНИКАТИВНАЯ СОСТАВЛЯЮЩАЯ ПРОФЕССИОНАЛЬНОГО МАСТЕРСТВА БУДУЩЕГО СПЕЦИАЛИСТА
}

\section{COMMUNICATIVE COMPONENT OF PROFESIONAL SKILLS \\ OF A FUTURE SPECIALIST}

\author{
L. Fedko \\ O. Taranenko \\ E. Shchepoteva \\ A. Ilintseva
}

Summary: Professionalism of knowledge - as a basis; professionalism of communication - both the willingness and ability to use the knowledge system in practice and the professionalism of self-improvement - these are three components in the structure of the professional skills of a future specialist. Communication skills allow to be actively engaged in a targeted communication process. The ability for self-control and self-assessment of achievements are indicators of the subject-personal competence and professional mobility of a young specialist.

Keywords: communication skills, professionalism, young specialist, learning process, self-control, self-esteem.

\section{Федько Людмила Александровна}

К.n.н., доцент, Дальневосточный федеральный университет, Владивосток fedko.la@dvfu.ru

Тараненко Ольга Ивановна Доцент, Дальневосточный федеральный университет, владивосток

taranenko.oi@dvfu.ru Щепотьева Екатерина Владимировна Старший преподаватель, Дальневосточный федеральный университет, Владивосток shchepoteva.ev@dvfu.ru

Ильинцева Анна Валерьевна

Старший преподаватель, Дальневосточный федеральный университет, Владивосток Ilintseva.av@dvfu.ru

Аннотация: Представлены три ключевых компонента в структуре профессионального мастерства будущего специалиста: профессионализм знаний - как базис; профессионализм общения - как готовность и умение использовать систему знаний на практике и профессионализм самосовершенствования. Подробно рассматривается коммуникативная составляющая. Коммуникативные умения позволяют активно включиться в целенаправленный процесс общения. Способность к самоконтролю и самооценка достижений выделяются как показатели субъектно-личностной компетенции и профессиональной мобильности молодого специалиста.

Ключевые слова: мастерство, профессионализм, молодой специалист, процесс обучения, коммуникативные умения, самоконтроль, самооценка.

образование и самовоспитание. В нашем представлении понятия мастерство и профессионализм неотделимы.

Ученые исследователи, рассматривая структуру профессионального мастерства, определяют три основных звена: профессионализм знаний; профессионализм общения - готовность и умение применять полученные знания на практике и установка на будущую профессиональную деятельность; профессионализм самосовершенствования - как звено, обеспечивающее динамичность, развитие целостной системы «основы профессионализма будущего специалиста» путем самооценивания и устранения личностных недостатков и недочетов в необходимых для специалиста знаниях, обнаружившихся в процессе профессионального общения.

Известный ученый исследователь И.П. Андриади считал, что коммуникация в обществе - это, прежде всего влияние, воздействие на другого человека [1, С.30]. Такое влияние представляет собой не что иное, как передачу информации и осуществляется путем взаимодей- 
ствия с другими людьми, т.е. в процессе межличностной коммуникации. В общении, по мнению известного ученого исследователя А.А. Реана, каждый из партнеров является активным субъектом данного процесса, определяющим его динамику и содержание, поэтому никого из них нельзя рассматривать в качестве объекта [6, С.64].

Выделяя различные подходы в определении структуры общения, И.П. Андриади подчеркивает, что в отечественной социальной психологии наиболее распространена структура с выделением трех его сторон: коммуникативной, интерактивной и перцептивной.

Обмен информацией между общающимися индивидами представляет коммуникативную сторону общения. Содержание, заключенное в сообщении, несет в себе не только ценности и эмоции, но и субъективизированные знания. Интерактивная сторона общения характеризуется взаимодействием собеседников. Другими словами, это обмен знаниями, идеями и действиями.

Восприятие, познание партнерами по общению друг друга и, как следствие, поиск взаимопонимания - характерны для перцептивной стороны общения. [1, С.140].

Профессиональную деятельность будущего специалиста, по оценке Н.Ф. Долгополовой, отличают следующие важные виды коммуникативных умений: рефлексивные, ориентировочные, прогностические, креативные, визуально-презентативные, полемические.

Чем лучше специалист владеет знаниями о коммуникациях, по словам Н.Ф. Долгополовой, тем более сознательно и грамотно он поступает в нестандартной обстановке, когда важность коммуникативных умений и навыков бесспорна [3, С.15].

Коммуникативные умения, в нашем представлении - это совокупность соответствующих интеллектуальнокоммуникативных действий, позволяющих энергично войти в целенаправленный процесс общения. Чтобы убедительно доказать что-либо, нужно знать как это делается.

В учебно-воспитательном процессе развитие коммуникативных умений обучающихся происходит в речевой деятельности. К данным умениям относятся: а) аудирование и чтение (рецептивные умения) и б) говорение и письмо (продуктивные умения). Это комплексные или интегративные умения.

Различные коммуникативные умения обычно неразделимы в оригинальном общении. Тем не менее, исследованиями В.А. Якунина, С.Л. Братченко подтверждается то, что в учебном процессе у студентов доминирует монологическая форма общения [10, С.94]., в то время как для современного специалиста существенен такой уровень развития личности, коммуникация которой характеризовалась бы диалогичностью.

В современной теории речевой деятельности диалог рассматривается как предмет вербального взаимодействия и соприкосновения между людьми в ходе совместной деятельности. Ключевым элементом диалога является построение речи двумя или несколькими участниками, при этом важно, что роли говорящего и слушающего меняются попеременно. На продуктивность диалога и часто на результаты профессиональной деятельности могут отрицательно влиять неблагоприятные характеристики личности: повышенная эмоциональность, тревожность, мнительность, чрезмерная профессиональная ответственность, вызывающая устойчивое беспокойство и озабоченность, скрытность и подозрительность, проникающие в сферу общения. Личность с низкой степенью развития коммуникативных умений, применяя неподобающие модели коммуникативного поведения, может побуждать других на такие же виды поведения и, следовательно, благоприятствовать ухудшению морально-психологической обстановки в профессиональном сообществе.

В рамках нашего исследования при обучении будущих специалистов коммуникативным умениям с помощью самоконтроля знаний мы придерживались положений, отраженных в нормативных документах высшего образования.

Существующие Федеральные государственные образовательные стандарты (ФГОС) для различных направлений подготовки в Политехническом институте Дальневосточного федерального университета (ПИ ДВФУ), по дисциплинам «Профессиональный иностранный язык», «Иностранный язык в профессиональной сфере», «Профессионально-ориентированный перевод», отражают не только общекультурные компетенции, связанные с владением иностранного языка в устной и письменной форме для формирования и реализации межкультурной и иноязычной коммуникации (ОК-7), способностью к коммуникации в устной и письменной формах на русском и иностранном языках для решения задач межличностного и межкультурного взаимодействия (ОК-12) , но также и профессионально-направленные компетенции, связанные со способностью и готовностью будущих специалистов к самоорганизации, самообразованию и саморазвитию. Например, для направления 13.04.02 «Электроэнергетика и электротехника», ФГОС ВО от 28.02.18 №147 рекомендует развивать УК-6 - способность определять и реализовать приоритеты собственной деятельности и способы ее совершенствования на основе самооценки; ОПК-2 - способность применять современные методы исследования, оценивать и представлять результаты выполненной работы и т.д.[7]. 
Самоконтроль и связанная с ним самооценка, - это признаки субъектно-личностной компетенции и профессиональной мобильности молодого современного специалиста.

В исследовании, которое мы проводили в ПИ ДВФУ, приняли участие студенты инженерно- технических направлений, составившие контрольную группу (КГ), где обучение осуществлялось по традиционной методике и экспериментальную группу (ЭГ), для которой занятия проходили по специально разработанным нами методическим материалам. В своей работе мы опирались на профессионально-ориентированные тексты и обучение затрагивало все виды речевой деятельности. Занятия по английскому языку проводились по учебному пособию «Power Engineering", разработанному преподавателями Академического департамента английского языка ДВФУ [5].

Студенты активно изучали словарь необходимой лексики, выполняли упражнения тренировочного характера, представляли микродиалоги, диалоги, игры и кроссворды. К текстам предлагались задания и вопросы по самоконтролю, которые представляли определенную коммуникативную задачу, ради которой студенты работали с текстом и осуществляли самоконтроль изученного материала. Большое внимание уделялось дискуссиям. Студенты отвечали на вопросы, высказывали и аргументировали свое мнение, оспаривали или соглашались с мнением других. Такая работа способствовала их самостоятельному анализу, оценке, отбору и творческому употреблению в речи предлагаемого материала.

Контроль и самоконтроль знаний осуществлялся с помощью ситуативных заданий, стимулировавших самостоятельные высказывания. Процесс обучению и формирования самоконтроля проходил через несколько этапов развития: подготовительный, относительный, избирательный, устойчивый и транспозиционный. [9, С.99].

Все виды самоконтроля (фронтальный, взаимный и индивидуальный) имеют одинаковое значение в учебном процессе, но чтобы достичь большей результативности на всех этапах обучения их рекомендуется сочетать.

На первом курсе фронтальный самоконтроль использовался на 40\% занятий; взаимный самоконтрольна 50\% занятий и индивидуальный - на 10\% занятий. На втором курсе фронтальный самоконтроль мы проводили на $30 \%$ занятий, взаимный - на 55\% занятий и индивидуальный - на $15 \%$ занятий. Индивидуальный самоконтроль стал основным видом контроля на третьем курсе. Он использовался на 55\% занятий, взаимный - на $35 \%$ занятий и фронтальный - на 10\% занятий.

В результате проведенного нами исследования мы отметили, что в условиях самоконтроля изменился стиль учебной деятельности и общения студентов ЭГ по сравнению со студентами КГ. Используя модифицированный вариант метода анализа взаимодействия Н. Фландерса, мы выяснили, что в результате обучения будущих специалистов коммуникативным умениям, применяя самоконтроль знаний, произошла трансформация учебной деятельности студентов ЭГ. Важным видом их работы стало коммуникативное взаимодействие всей группы в парах, появился взаимный контроль. Время практики каждого из них на учебном занятии возросло по сравнению с работой студентов в контрольной группе. Выделяя критерии оценки речевых умений (а - количество реплик, включая фразы, построенные по образцам английского языка; 6 - наличие в репликах фраз, стимулирующих собеседника в продолжении общения; с - количество фонетических и грамматических ошибок ) мы отметили, что у обучающихся в экспериментальной группе объем высказываний увеличился в 2-3 раза, речевые высказывания стали содержательнее. Монологическая речь получила большую мотивированность, окрасилась личностным отношением, обрела цель и направленность. Это был ответ не только на оценку. Во время своей работы студенты были внимательны к возможным ошибкам, они не только слышали, но и слушали свой ответ, затем анализировали и оценивали его. Вовлеченность в процесс труда позволила повысить и их продуктивность, т.к. студенты сами управляли обстановкой.

При обучении будущих специалистов коммуникативным умениям как составляющей профессионального мастерства путем самоконтроля знаний, мы изучили структурные компоненты знания иностранного языка: лексика, грамматика, устная речь - говорение и аудирование, профессионально-ориентированное чтение и перевод. Речевые социокультурные знания, навыки и умения способствовали формированию коммуникативной компетентности, т.е. готовности и способности использовать иностранный язык в процессе межкультурного общения [8, С.100].

Применение новых форм взаимодействия преподавателя со студентами и студентов между собой, когда последние сами формулируют вопросы, и сами заняты поиском информации, трансформирует обучение в интерактивное, когда повышается мотивация обучения, развивается любознательность, желание учиться. Студенты становятся более уверенными и эмоционально устойчивыми, обеспечивается рефлексия собственной деятельности и умение наглядно представить результаты собственной деятельности, что сыграет большую роль в перспективной профессиональной деятельности молодого специалиста. 


\section{ЛИТЕРАТУРА}

1. Андриади И.П. Основы педагогического мастерства. - М.: Издательский центр «Академия», 1999.-160 с.

2. Горшкова 0.0. Формирование познавательной активности студентов технических вузов как средство подготовки к инновационной деятельности// Современные проблемы науки и образования. - 2005. - № 2.

3. Долгополова Н.Ф. Развитие коммуникативных умений студентов-менеджеров в условиях университета: Автореф.дис. ... канд.пед.наук. - Оренбург, 2007. $-20 \mathrm{c}$.

4. Кузьмина Н.В. Профессионализм деятельности преподавателя и мастера производственного обучения. - М.: Высшая школа, 1989.-168 с.

5. Power Engineering. Английский язык : учеб. пособие для обучающихся по направлениям 3.04 .01 Теплоэнергетика и теплотехника/ Технология производства тепловой и электрической энергии на электростанциях, 13.04.02 Электроэнергетика и электротехника / Автоматизированные электротехнические комплексы и системы в судовой энергетике, 13.04.02 Электроэнергетика и электротехника/ Оптимизация развивающихся систем электроснабжения, 13.04.02 Электроэнергетика и электротехника/ Энергоэффективность и энергосбережение в электроэнергетических системах и др. / сост.: Л.А. Федько, 0.И. Тараненко - Владивосток : Дальневост. федерал. ун-т, 2020. - 136 с.

6. Реан А.А. Психология педагогической деятельности. - Ижевск: Изд-во Удмурртского ун-та, 1994. - 81 с.

7. Федеральный государственный образовательный стандарт высшего образования - магистратура по направлению подготовки 13.04 .02 «электроэнергетика и электротехника» от 28.02.2018, № 147 / Министерство образования и науки Российской Федерации. - М.: Консультант Плюс, 2020

8. Федько Л.А., Тараненко О.И., Щепотьева Е.В. Полезный ресурс совершенствования учебной активности в вузе// Современная наука: актуальные проблемы теории и практики. Серия: Гуманитарные науки. -2020. -№02/2. -С. 98-101 D01 10.37882/2223-2982.2020.06-2.33

9. Федько Л.А., Тараненко О.И., Щепотьева Е.В. Самоконтроль и самооценка как составляющие самоорганизации в современном учебном процессе // Современная наука: актуальные проблемы теории и практики. Серия: Гуманитарные науки. -2020. -№66/2. -C. 98-101 D0I 10.37882/2223-2982.2020.06-2.33

10. Якунин В.А. Обучение как процесс управления. Психологические аспекты. - Л.,1988. - 155 с.

○ Федько Людмила Александровна (fedko.la@dvfu.ru), Тараненко Ольга Ивановна (taranenko.oi@dvfu.ru), Щепотьева Екатерина Владимировна (shchepoteva.ev@dvfu.ru), Ильинцева Анна Валерьевна (llintseva.av@dvfu.ru).

Журнал «Современная наука: актуальные проблемы теории и практики»

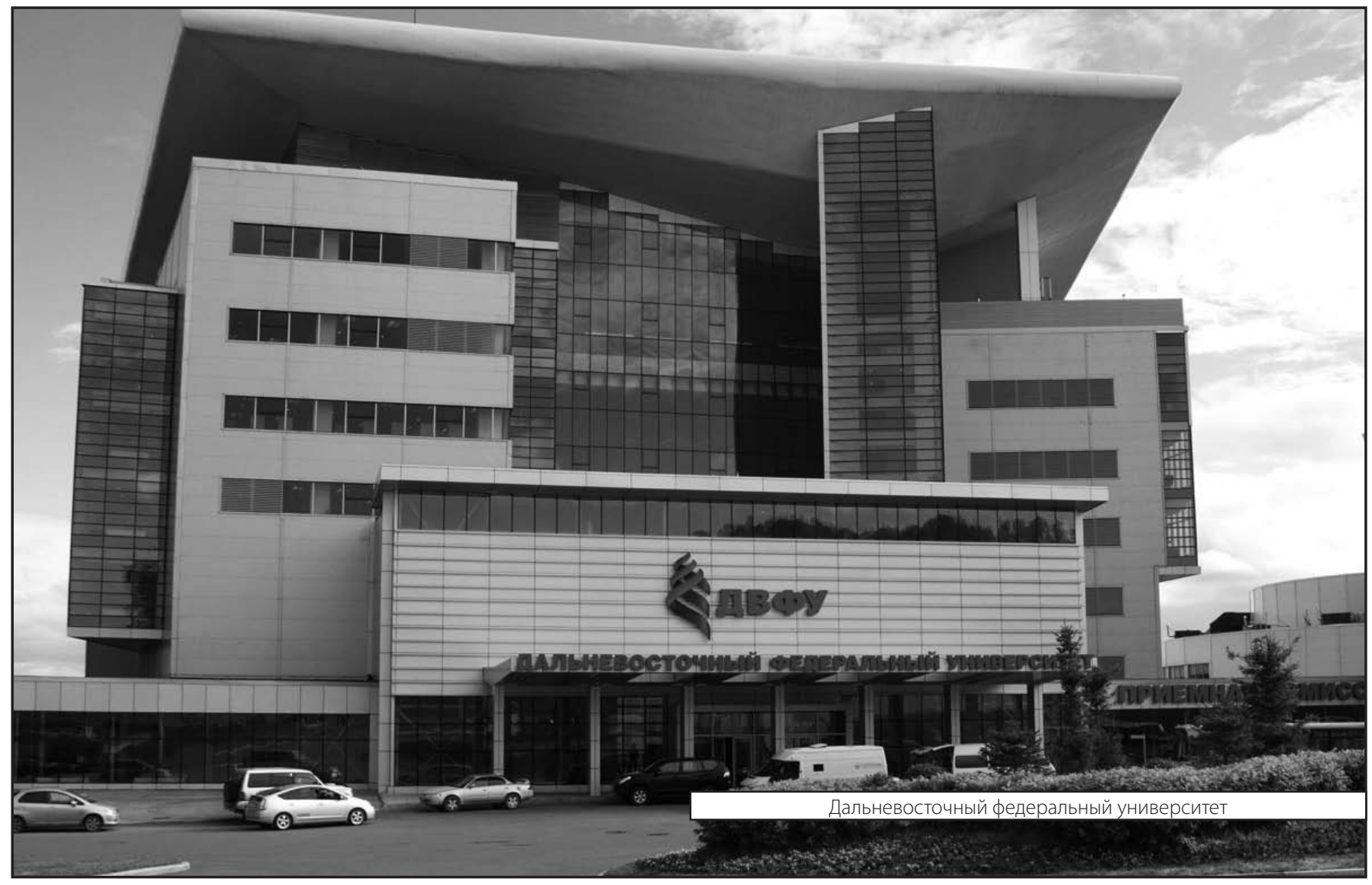

